\title{
PREFACE TO THE REVISED EDITION
}

The two senior authors, John E. Werler and James R. Dixon, were lifelong, highly accomplished, and well-respected herpetologists, conservationists, and mentors to many of the current generation of herpetologists and naturalists. More than ten years ago, their guide to Texas snakes became the book that everyone curious about or enthralled by snakes must have. It is my privilege to update their field guide to Texas snakes here. The guiding principle for my task in revision was simply to not break what wasn't broken. Updates have been made throughout to retain the successful depth and utility of the text for all readers, from casual hikers to professional herpetologists. I am grateful for the years of friendship and mentorship, and for always being treated as family by both of my coauthors and their kin. Their absence is still felt acutely, but their wisdom will remain in our backpacks as this field guide continues to provide insights from their work and encouragement to the next generation of naturalists.

MICHAEL R. J. FORSTNER, 2019 